Ewa Kowalewska-Borys

\title{
PREKLUZJA DOWODOWA W PROCESIE KARNYM NA PRZYKŁADZIE PRZEPISU ART. 170 § 1 PKT 5 KPK.
}

\section{Uwagi wprowadzające}

Problematyka znaczenia czasu w polskim procesie karnym jest niezwykle istotna. Nie chodzi tu tylko o fundamentalną kwestię nakazu szybkości całego postępowania karnego wyrażonego expressis verbis w przepisie art. $2 \S 1$ pkt 4 kpk., zgodnie z którym rozstrzygnięcie sprawy powinno nastapić w rozsądnym terminie, a który to nakaz został niejako „wymuszony” przez regulację art. 6 ust. 1 EKPC ${ }^{1}$, określającego prawo do rozpatrzenia sprawy w rozsądnym terminie (within a reasonable time) przez niezawisły i bezstronny sąd i ściśle związane z tym nakazem, szczegółowe przepisy proceduralne, normujące terminy dla dokonywania określonych czynności procesowych. Problematyka znaczenia czasu w polskim procesie karnym to również ciagle stawiane i rozważane pytanie, o przyszłość i kierunek ewolucji nowoczesnego (w rozumieniu najefektywniej odpowiadającego ciągłym zmianom stosunków społecznych sensu largo) modelu procesu karnego. To właśnie pytanie o kierunek ewolucji i związanych z nią nowelizacji kodeksu postępowania karnego skłania do podjęcia rozważań dotyczących funkcji i interpretacji przepisu art. 170 $\S 1$ pkt 5 kpk., stanowiącego podstawę oddalenia wniosku dowodowego, gdy ów wniosek „w sposób oczywisty zmierza do przedłużenia postępowania” z perspektywy wyznaczonych celów modelowych zmian polskiego procesu karnego. ${ }^{2}$

\footnotetext{
1 Europejska konwencja o ochronie praw człowieka i podstawowych wolności z dnia 4 listopada 1950 r., dalej jako EKPC.

2 S. Waltoś, O obstrukcji procesowej, czyli kilka uwag o nadużyciu prawa procesowego, (w:) W kręgu teorii i praktyki prawa karnego, s. 620, 624; C. Kulesza, Efektywność udziału obrońcy w procesie karnym w perspektywie prawnoporównawczej, Kraków 2005, s. 366; K. Zgryzek, Oddalenie wniosku dowodowego w nowelizacji kodeksu postępowania karnego z 2003 r., (w:) Aktualne problemy prawa i procesu karnego, GSP 2003, t. XI, s. 169; T. Grzegorczyk, Komentarz, s. 418; J. Grajewski, S. Steinborn, Nowelizacja kodeksu postępowania karnego z dnia 10 stycznia 2003 r. (cz. I), EP 2003, nr 8, s. 10; M. Wąsek-Wiaderek, Oddalenie wniosku dowodowego zmierzającego w sposób oczywisty do przedłużenia postępowania w polskiej procedurze karnej, (w:) W kręgu teorii i praktyki prawa karnego. Księga poświęcona pamięci profesora Andrzeja Wąska, red. L. Leszczyński, E. Skrętowicz, Z. Hołda, Lublin 2005, s. 711; P. Girdwoyń, Zarys kryminalistycznej taktyki obrony, Karków 2004, s. 304
} 
Wychodząc z założenia, że normy prawne regulują stosunki społeczne sensu largissimo, należy dojść przede wszystkim do wniosku, że wraz z rozwojem tychże stosunków musi zmieniać się również prawo je regulujące, tak aby nadążyć za dynamiczną rzeczywistością. Niemniej jednak zarówno prawodawca, jak i interpretator tychże norm prawnych powinni mieć również na względzie specyfikę danej kategorii stosunków społecznych oraz sytuację wszystkich stron danego stosunku prawnego, stąd też radykalna zmiana kodyfikacji karnych w 1997 r., po przełomie ustrojowym 1989 r. Od tamtego okresu normy prawa karnego (sensu largo) podlegają „szybkim” nowelizacjom. Częściowo stanowią wynik bardziej lub mniej przemyślanych założeń polityki kryminalnej. Niestety, widoczny jest również wpływ populistycznych haseł politycznych. Polski ustawodawca, dążąc do maksymalnego usprawnienia postępowania karnego i wprowadzając nowe instrumenty prawne (np. instytucję świadka koronnego, konsensualizm w trybie art. 335 (343) oraz 387 kpk., nowy kształt normatywny postępowania przyspieszonego), wpływa niewątpliwie na zmianę struktury i balansu całego postępowania karnego. Wydaje się, że umniejszona zostaje rola rozprawy sądowej, a faktyczne przesunięcie struktury procesu karnego następuje na etapie postępowania przygotowawczego. W ten sposób coraz mniej czytelna staje się koncepcja prawna leżąca u podstaw całego polskiego procesu karnego.

Znamiennym przykładem takich zmian jest wprowadzenie do kodeksu postępowania karnego nowej podstawy oddalenia wniosku dowodowego na mocy noweli z dnia 10 stycznia 2003 r. $^{3}$, która może być postrzegana jako quasi-prekluzja dowodowa ${ }^{4}$ w procesie karnym. Zgodnie bowiem z art. $170 \S 1$ pkt 5 kpk. „oddala się wniosek dowodowy, jeżeli wniosek dowodowy w sposób oczywisty zmierza do przedłużenia postępowania". Paradoksalnie zmiana ta, mająca w zamierzeniu ustawodawcy, w racjonalny sposób ułatwić i usprawnić etap postępowania dowodowego, w praktyce nie wydaje się już tak oczywista ani tym bardziej tak prosta w zastosowaniu. Ponadto odnosi się wrażenie, że aksjologicznie nie jest ona do pogodzenia z podstawowymi zasadami procesu karnego (np. zasadą prawdy materialnej czy ścigania z urzędu etc.).

\section{Problematyka inicjatywy dowodowej w procesie karnym z uwzględnieniem regulacji art. 170 § 1 pkt 5 kpk.}

W polskim procesie karnym sąd rozpoznający sprawę związany jest obowiązkiem dojścia do prawdy materialnej. Zasada prawdy materialnej, będąca nadrzędną

\footnotetext{
3 Ustawa z dn. 10 stycznia 2003 r. o zmianie ustawy - Kodeks postępowania karnego, ustawy - Przepisy wprowadzające Kodeks postępowania karnego, ustawy o świadku koronnym oraz ustawy o ochronie informacji niejawnych, Dz.U. Nr 17, poz. 155.

$4 \quad$ W znaczeniu ograniczeń dotyczących dowodów z uwagi na upływ czasu.
} 
zasadą karnoprocesową i jednocześnie fundamentalną wskazówką interpretacyjną, skodyfikowana została w przepisie art. $2 \S 2$ kpk., mocą którego sąd karny oraz inne organy procesowe zobligowane są do dokonywania prawdziwych ustaleń faktycznych stanowiących podstawę każdego rozstrzygnięcia, każdej decyzji procesowej. Podkreślił to Sąd Najwyższy w swoim wyroku z dnia 14 marca 1996 r. (V KKN $1 / 96)^{5}$, stwierdzając, że ,polski system prawny nie zwalnia sądu od obowiązku dochodzenia prawdy jako podstawy wydawanych orzeczeń, także w drodze własnej inicjatywy dowodowej, niezależnie od ponoszenia ciężaru dowodu przez oskarżyciela publicznego, który w tym zakresie nie przejawia dostatecznej aktywności”. Niewypełnienie tego obowiązku przez sąd w konkretnych okolicznościach oznaczać może naruszenie przepisów postępowania, mogące mieć wpływ na treść rozstrzygnięcia i uzasadniać konieczność uchylenia wyroku. ${ }^{6}$ Wprowadzony nowelą z $2003 \mathrm{r}$. przepis art. $170 \S 1$ pkt 5 kpk., interpretowany ściśle jako samodzielna i wyłączna podstawa oddalenia wniosku dowodowego i w tym sensie mająca charakter bezwzględny, oznacza ograniczenie dojścia sądu karnego do prawdy materialnej. Mając zaś na uwadze fakt, iż prawo karne sensu largo reguluje stosunki prawne, w których istotą jest brak równorzędności podmiotów tych stosunków, tj. występowanie „słabszej, nieprofesjonalnej” strony - oskarżonego i strony „silniejszej, profesjonalnej” - prokuratora i innych organów państwowych, wyposażonych dodatkowo w kompetencję do stosowania środków przymusu bezpośredniego, stwierdzić należy, że nawet quasi-prekluzja dowodowa $\mathrm{z}$ art. $170 \S 1$ pkt $5 \mathrm{kpk}$. tworzy zagrożenie nie tylko prawa do obrony (wszak obrońca nie jest obligatoryjnym uczestnikiem każdego procesu karnego), ale również zasady równouprawnienia stron procesowych, mając w ten sposób bezpośredni wpływ na prawidłowe wyrokowanie.

Poznanie prawdy i dochodzenie do niej nie jest oczywiście pozostawione wyłącznie sądowi i innym organom procesowym. Inicjatywa dowodowa zgodnie z przepisem art. 167 kpk., spoczywa również na stronach procesowych oraz podmiocie określonym w art. $416 \mathrm{kpk}$. (tj. podmiocie zobowiązanym do zwrotu w całości lub części korzyści majątkowej na rzecz Skarbu Państwa, który uzyskał tę korzyść wskutek przestępstwa popełnionego przez sprawcę działającego w jego imieniu lub interesie). Ilustruje to następujące stwierdzenie SN, według którego sądy sprawują wymiar sprawiedliwości, którego funkcją jest przede wszystkim weryfikacja dowodów, natomiast ich gromadzenie i zgłaszanie przypada innym organom albo innym podmiotom. O ile zatem odstapienie przez sąd od takiego podziału ról procesowych może być zrozumiałe wówczas, gdy podmioty te oskarżają bez fachowej pomocy, o tyle przejawianie inicjatywy dowodowej przez sąd, zamiast występującego w sprawie prokuratora lub pełnomocnika, może spotkać się z zarzutem 
naruszenia zasady bezstronności. ${ }^{7}$ Takie rozumienie roli sądu w zakresie inicjatywy dowodowej jest niewątpliwie słuszne i zgodne z zasadą kontradyktoryjności, rozumianej jako dyrektywa prowadzenia procesu karnego w formie sporu równouprawnionych stron przed bezstronnym sądem.

$\mathrm{Z}$ problematyką inicjatywy dowodowej w procesie karnym ściśle związana jest podstawowa dla niniejszych rozważań kwestia oddalenia wniosku dowodowego. Przepis art. $170 \S 1$ kpk. stanowi, iż oddala się wniosek dowodowy, jeżeli zachodzi jeden z taksatywnie wymienionych ustawowych powodów oddalenia wniosku dowodowego: niedopuszczalność przeprowadzenia dowodu, brak znaczenia wskazywanej okoliczności dla rozstrzygnięcia sprawy, udowodnienie wskazywanej okoliczności zgodnie z twierdzeniem wnioskodawcy, nieprzydatność dowodu do stwierdzenia danej okoliczności, niemożność przeprowadzenia dowodu oraz oczywistość zamiaru przedłużenia procesu karnego wskutek składanego wniosku dowodowego. Z uwagi na to, iż możliwość oddalenia wniosku dowodowego jest ścisle związana z prawem stron do wpływania na rodzaj materiału dowodowego, który powinien być zebrany w kontradyktoryjnym postępowaniu dla prawidłowego rozstrzygnięcia, a w związku z tym stanowi bezpośrednie przełożenie na obowiązek sądu dochodzenia do prawdy materialnej, przeto i nie jest tu dopuszczalna interpretacja rozszerzająca. ${ }^{8}$ Jak wynika z powyższego katalogu, wszystkie wyszczególnione tam powody oddalenia wniosku dowodowego dotyczą zasadności dowodu, którego przeprowadzenie może przyczynić się do realizacji zasady prawdy materialnej oraz jego prawnej dopuszczalności. Ocena tych przesłanek odnosi się do głównego celu procesu karnego - orzeczenia w przedmiocie odpowiedzialności karnej (cywilnej) w oparciu o prawdziwe ustalenia faktyczne, nie zaś do subiektywnych motywów i celów podmiotu składającego wniosek dowodowy. A zatem, w zarysowanym powyżej kontekście nie może decydować wyłącznie okoliczność, że podmiot składający wniosek dowodowy mógł go złożyć wcześniej lub też, że nawet pod koniec przewodu sądowego zdecydował się w końcu skorzystać z przysługującego mu prawa inicjatywy dowodowej. Ponadto, jak słusznie zauważa A. Gaberle, wykorzystanie prawa do obrony $z$ reguły utrudnia przebieg procesu (czas wymagany na przeprowadzenie wnioskowanych przez oskarżonego czynności, wnioskowane w tym celu przerwy i odroczenia rozprawy), może też być drażniące i niezwykle rzadko wprawiające sąd w dobry humor. ${ }^{9}$ Podkreślić w związku z tym należy, że zasadne wnioski dowodowe, choć przedłużają rozprawę, nie powodują ,obstrukcji procesowej”, służą zasadzie prawdy materialnej oraz zasadzie ścigania z urzędu. Natomiast w przeciwnym wypadku, w razie rzeczywistej bezzasadności, powinny zostać odda-

$7 \quad$ Postanowienie SN z 18 listopada 2003 r., III KK 505/02, Lex nr 82314.

8 Zob. wyrok SN z dn. 28 lipca 1980 r., III KR 223/80, OSNPG 1981, nr 2, poz. 26; wyrok SN z dn. 15 kwietnia 1981 r., IV KR 60/81, OSNPG 1981, nr 11, poz. 120; wyrok SN z 12 lipca 1988 r., IV KR 176/88, OSNPG 1988, nr 12, poz. 138; wyrok SN z 7 grudnia 1988 r., IV KR 116/88, OSNKW 1989, nr 3-4, poz. 30 
lone w oparciu o przepis art. $170 \S 1 \mathrm{pkt} 1-4 \mathrm{kpk}$. W związku z tym podnieść należy, iż dokonując oceny powodów oddalenia wniosku dowodowego, bez znaczenia są intencje wnioskodawcy, czas znajomości wnioskowanych okoliczności i dowodów, a także sam termin składania wniosku dowodowego. Jest to zgodne ze stanowiskiem SN, według którego procedura karna nie ustanawia terminu, do którego oskarżony może składać wnioski dowodowe. (...) Nie ma też znaczenia okoliczność, od jakiego momentu oskarżony miał możliwość zawnioskowania danego dowodu. ${ }^{10}$ Niemniej jednak wskazać należy, iż występujące w ustawie - kodeks postępowania karnego terminy do składania przez oskarżonego wniosków dowodowych mają charakter jedynie instrukcyjny. Tytułem przykładu wskazać należy następujące przepisy prawne regulujące terminy składania wniosków dowodowych: art. $315 \S$ $1 \mathrm{kpk}$. (wnioski o dokonywanie czynności procesowych w postępowaniu przygotowawczym), $321 \S 5 \mathrm{kpk}$. (instytucja końcowego zaznajomienia z materiałami postępowania), $338 \S 1 \mathrm{kpk}$. (doręczenie aktu oskarżenia; odpowiedź na akt oskarżenia), $352 \mathrm{kpk}$. (dopuszczenie dowodów), $368 \mathrm{kpk}$. (rozstrzyganie o wnioskach dowodowych), $369 \mathrm{kpk}$. (porządek przeprowadzania dowodów), $405 \mathrm{kpk}$. (zamknięcie przewodu sądowego), $409 \mathrm{kpk}$. (instytucja wznowienia przewodu sądowego), $427 \S 3$ kpk. (nowe fakty lub dowody; wymogi formalne środka odwoławczego). Jak widać z powyższego przykładowego wyliczenia, przez cały czas trwania postępowania karnego istnieje możliwość składania wniosków dowodowych, a to w celu poznania prawdy o okolicznościach popełnienia przestępstwa w procesie karnym, w celu realizacji zasady prawdy materialnej.

Z punktu widzenia zakreślonych rozważań niezwykle istotne znaczenie ma stanowisko SN wyrażone w wyroku z dnia 22 czerwca 2004 r., zgodnie z którym „późne złożenie wniosku dowodowego nie może wpłynąć na jego oddalenie, gdyż oskarżony nigdy nie ma obowiązku dowodzenia swej niewinności (art. $741 \mathrm{kpk}$.). $\mathrm{Z}$ uprawnienia może zatem skorzystać na każdym etapie postępowania, także w drugiej instancji, poprzedzającym zamknięcie przewodu sądowego." ${ }^{11}$ Wprowadzenie zatem do procesu karnego prekluzji dowodowej, rozumianej jako ograniczenie w czasie dopuszczalności przedstawiania sądowi przez oskarżonego faktów i dowodów na poparcie własnych twierdzeń, niewątpliwie rozmijałoby się z regułą nemo se ipsum accusare tenetur. Ponadto zauważyć należy, że ostateczna weryfikacja materiału dowodowego następuje co do zasady na rozprawie, przed sądem orzekającym, który podejmuje decyzję w przedmiocie odpowiedzialności karnej (cywilnej) oskarżonego. Potwierdza to następujący wyrok Sądu Najwyższego, w którym SN podkreślił, iż w sferze oceny dowodów zasadniczy układ odniesienia stanowią dowody przeprowadzone przez sąd orzekający, co łączy się z dwoma podstawowymi zasa-

\footnotetext{
10 Wyrok SN z dn. 9 grudnia 2003 r., III KK 133/03, Lex nr 83760; wyrok SN z dn. 17 października 2002 r., IV KK 237/02, Lex nr 56865

11 Wyrok SN z 22 czerwca 2004 r., V KK 54/04, Lex nr 109522.
} 
dami procesu karnego: zasadą bezpośredniości oraz zasadą kontradyktoryjności, silnie powiązanymi z inną naczelną zasadą procesową, a mianowicie prawem oskarżonego do obrony. Innymi słowy, materiałem wyjściowym dla ustaleń faktycznych są dowody przeprowadzone na rozprawie (art. $410 \mathrm{kpk}$.). Nie oznacza to jednak, że dowody utrwalone w postępowaniu przygotowawczym pozbawione są znaczenia. Służą one bowiem weryfikacji oświadczeń złożonych na rozprawie, wówczas gdy dochodzi między nimi do zasadniczych sprzeczności (np. 389, $391 \mathrm{kpk}$.) lub też są wykorzystywane przez sąd, gdy bezpośrednie przeprowadzenie dowodu ,nie jest niezbędne" (art. 392, 393 kpk.). Wyrażony przez sąd pogląd na wynik tej weryfikacji tylko wtedy pozostaje poza możliwością jego zakwestionowania i jest chroniony przepisem art. $4 \S 1 \mathrm{kpk}$. (obecnie art. $7 \mathrm{kpk}$. - EKB), gdy przedmiotem rozważań sądu był całokształt okoliczności sprawy i to w sposób podyktowany obowiązkiem dochodzenia prawdy. ${ }^{12}$ Oznacza to, że postępowanie dowodowe w polskim procesie karnym ma charakter dynamiczny i rozwojowy, co z kolei w konsekwencji musi prowadzić do wniosku, że w procesie karnym nie da się bezwzględnie zakreślić ram czasowych składania przez oskarżonego wniosków dowodowych, a to tym bardziej, gdy występuje on w procesie bez pomocy profesjonalisty - obrońcy.

W tym miejscu nie sposób nie poruszyć kwestii ewentualnego zagrożenia zasady kontradyktoryjności, która zakłada równouprawnienie stron, która, aby spór przed niezawisłym sądem był rzeczywisty, dotyczy nie tylko samej istoty regulacji prawnej i przyznanych spierającym się stronom uprawnień, lecz głównie chodzi tu o faktyczną możliwość korzystania z przyznanych przez ustawodawcę uprawnień. Niewątpliwie bez obligatoryjnej pomocy adwokata - obrońcy dla oskarżonych w zakresie prekluzji dowodowej nie może być mowy o równości broni stanowiącej przecież warunek sine qua non prawidłowości toczącego się sporu i realizacji kontradyktoryjności. Należy zatem zaznaczyć, że równouprawnienie stron procesowych w rozumieniu przyznania określonych uprawnień procesowych i środków prawnych nie jest tożsame z faktyczną możliwością dysponowania przyznanymi prawami.

Wprowadzenie do katalogu przepisu art. $170 \mathrm{kpk}$. nowego powodu oddalenia wniosku dowodowego oznacza, że stanowi on samodzielną podstawę oddalenia wniosku dowodowego z powodu „oczywistego jego zmierzania do przedłużenia postępowania". ${ }^{13}$ A w związku z tym, jak słusznie wyraził to A. Gaberle, powołując się na ten przepis, można by oddalić wniosek o przeprowadzenie dowodu, który łącznie spełnia następujące warunki: jego przeprowadzenie jest dopuszczalne, ma służyć udowodnieniu okoliczności mającej znaczenie dla rozstrzygnięcia sprawy, ma służyć udowodnieniu okoliczności jeszcze nieudowodnionej, jest przydatny do stwierdzenia danej okoliczności i da się przeprowadzić. Skonstatować zatem nale- 
ży, że sam, nawet oczywisty zamiar wnioskodawcy „przedłużenia postępowania” nie może uzasadnić takiego naruszenia naczelnej zasady prawdy materialnej. $\mathrm{Z}$ wyroku SA w Lublinie z 2002 r. (sic!), w którym sąd ten stwierdził, iż składanie przez oskarżonego lub jego obrońcę licznych wszakże (E.K.B.) bezzasadnych! wniosków dowodowych odnośnie do okoliczności, które znane były oskarżonemu lub jego obrońcy już na etapie postępowania przygotowawczego, dopiero na ostatniej rozprawie kończącej bardzo długo toczące się postępowanie jurysdykcyjne świadczy ewidentnie o dążeniu do obstrukcji procesowej, o traktowaniu prawa do obrony w sposób instrumentalny i utrudniający sprawny przebieg procesu karnego w celu jego zablokowania lub wykolejenia"14, wynika, iż oprócz „przedłużania postępowania” wniosek dowodowy powinien mieć cechę bezzasadności. Nie sposób jej wszakże wyinterpretować z literalnego brzmienia omawianego przepisu. Wszelkie zaś argumenty wyjaśniające lub uzasadniające tę regulację jedynie w zakresie technicznego (formalnego), nie zaś merytorycznego kryterium oceny powodu oddalenia wniosku dowodowego, są w sprzeczności do założeń zasady prawdy materialnej, ścigania z urzędu, zasady swobodnej oceny dowodów, bezpośredniości postępowania dowodowego, obiektywizmu czy nawet zasady kontradyktoryjności. ${ }^{15}$

Należy poprzeć słuszny postulat P. Hofmańskiego i A. Gaberle, aby nową podstawę oddalenia wniosku dowodowego interpretować w ścisłym związku z przepisem art. $170 \S 2$ kpk. w następujący sposób: „Nie można oddalić wniosku dowodowego na tej podstawie, że dotychczasowe dowody wykazały przeciwieństwo tego, co wnioskodawca zamierza udowodnić, chyba że wniosek dowodowy w sposób oczywisty zmierza do przedłużenia postępowania"16.

\section{Oddalenie wniosku dowodowego z powodu zmierzania do przedłużenia postępowania w niemieckim procesie karnym}

Prawna możliwość oddalenia wniosku dowodowego, który zmierza do przedłużenia postępowania karnego (Prozessverschleppungsabsicht) istnieje również w niemieckim kodeksie postępowania karnego $(\mathrm{StPO})^{17}$ w przepisie $\S 244$ ust. 3 zd. 2. W stosunku do tej podstawy oddalenia wniosku dowodowego Federalny Sąd Najwyższy Republiki Federalnej Niemiec (BGH) wykluczył możliwość interpretacji wyłącznie w oparciu o kryterium ,formalne”, gdyż jego zdaniem nie jest wy-

\footnotetext{
14 Wyrok SA w Lublinie z 6 lutego 2002 r., II Aka 222/01, „Wokanda” 2002, nr 5, s. 46.

15 Zob. np. M. Wąsek-Wiaderek, Oddalenie wniosku dowodowego zmierzającego w sposób oczywisty do przedłużenia postępowania w polskiej procedurze karnej, (w:) W kręgu teorii i praktyki prawa karnego. Księga poświęcona pamięci profesora Andrzeja Wąska, red. L. Leszczyński, E. Skrętowicz, Z. Hołda, Lublin 2005, s. 712 i nast. 718.

16 P. Hofmański i in., Kodeks postępowania karnego. Komentarz, t. I, s. 756, A. Gaberle, Dowody..., s. 66.

17 StPO, Strafprozessordnung - niemiecki kodeks postępowania karnego w ujęciu z dn. 7 kwietnia $1987 \mathrm{r}$.
} 
starczająca jedynie zwykła zwłoka przy składaniu wniosku dowodowego. ${ }^{18}$ Wymagane jest natomiast: 1. stwierdzenie po stronie wnioskodawcy wyłącznie zamiaru opóźnienia zakończenia postępowania jurysdykcyjnego na czas bliżej nieokreślony, (BGH NStZ 82, 391; StV 86, 418) 2. ustalenie, że wnioskodawca ma świadomość, że składany wniosek dowodowy nie spowoduje korzystnego dla niego przełomu w postępowaniu (BGH NStZ 82, 391), oraz 3. przekonanie również sądu orzekającego o nieprzydatności danego dowodu (BGH NJW 82, 2201; NStZ 84, 230; 90, $350 \mathrm{z}$ glosą Wendisch). ${ }^{19} \mathrm{~W}$ literaturze niemieckiej podnosi się, iż ustalenie pierwszej i drugiej okoliczności może odbyć się jedynie w oparciu o całokształt zachowania się wnioskodawcy w czasie rozprawy jurysdykcyjnej i przyjętą przez niego linię obrony. ${ }^{20}$ Chodzi tu w szczególności o to, iż złożenie przez wnioskodawcę danego wniosku dowodowego (który zmierza do przedłużenia postępowania karnego) stanowi zachowanie niewytlumaczalne w żaden sposób w odniesieniu do dotychczasowego jego zachowania, jest wewnętrzne sprzeczne, niejednolite, niekonsekwentne. Ponadto zamiar przedłużenia postępowania karnego można również ustalić w sytuacji, gdy wnioskodawca jest nadaktywny w korzystaniu ze swoich uprawnień procesowych, tzn. domaga się przeprowadzenia każdego dowodu, składając w tym celu bezzasadne wnioski dowodowe lub też w sytuacji, gdy bez widocznej przyczyny, zmienia przyjętą wcześniej linię obrony i po nieudaniu się wcześniejszych zamierzeń żąda dokonywania ustaleń zupełnie sprzecznych faktów, wnioskując o przeprowadzenie trudno dostępnych lub w ogólne nieosiagalnych dowodów. O dążeniu do obstrukcji procesowej i instrumentalnym wykorzystywaniu przyznanych praw można wnosić również w przypadku, gdy strona wnioskuje na nowo o przeprowadzenie dowodu, który wcześniej wycofała, bez podania żadnego uzasadnienia takiej decyzji. Podkreślić wszakże należy, iż przy ocenie zamiaru przedłużenia procesu wskutek złożenia wniosku dowodowego decydujące jest kompleksowe spojrzenie sądu dokonującego oceny zamiaru, z jakim wnioskodawca składa wniosek dowodowy. Natomiast wskazane powyżej typy zachowań niewątpliwie mogą stanowić poszlaki świadczące o prawdziwych intencjach wnioskodawcy, a ponieważ niezwykle trudno jest móc ustalić i udowodnić rzeczywiste intencje wnioskodawcy, wydaje się, że niezbędne jest zapytanie wnioskodawcy o cel składanego wniosku dowodowego i przedstawienie leżących u podstaw wnioskowanego dowodu informacji. Brak zatem wykazania przez wnioskodawcę interesu w przeprowadzeniu ważnego dla jego

18 Zob. BGH Neue Zeitschrift für Strafrecht (NStZ) 2005, 395; BGH Neue Zeitschrift für Strafrecht (NStZ) 2007, 112, 113; BGH Neue Juristische Wochenschrift (NJW) 2005, 2466, 2467; Neue Zeitschrift für Strafrecht (NStZ) 1986, 371; Neue Zeitschrift für Strafrecht (NStZ) 1990, 350, 351; Neue Zeitschrift für Strafrecht (NStZ) 1992, 248; Neue Zeitschrift für Strafrecht (NStZ) 1992, 346.

19 BGHSt 21, 121; Neue Zeitschrift für Strafrecht (NStZ) 1998, 207 z glosa Sandera; BGH JR 1983, 35; 1985,35 z glosą Meyera.

20 Zob V. Krey, Deutsches Strafverfahrensrecht, Studienbuch in systematisch - induktiver Darstellung, t. II, Stuttgart 2007, s. 1077 i nast.; P. Greiser, H. Artkämper, Der „gestörte“ Hauptverhandlung-eine praxisorientierte Fallübersicht, Bielefeld 2001, s. 148; F.-Ch. Schroeder, Strafprozessrecht, wyd. IV, München 2007, s. 176, 237 i nast. 
sytuacji procesowej dowodu może oznaczać właśnie ów zamiar instrumentalnego nadużycia prawa inicjatywy dowodowej. W tym miejscu wypada zaznaczyć, że również w przypadku, gdy obrońca oskarżonego składa wniosek dowodowy, istotne jest zbadanie i ustalenie, czy działa on z zamiarem przedłużenia prowadzonego procesu. Nie chodzi przy tym o zamiar samego oskarżonego, nawet jeżeli wniosek dowodowy obrońca składa w imieniu swojego klienta, występując w tym wypadku raczej w roli „narzędzia”, ale podobnie jak w przypadku samego wnioskodawcy, ustalenie zamiaru przedłużenia procesu wskutek złożenia wniosku dowodowego powinno odbywać się w oparciu o całokształt zachowania obrońcy, sposobu prowadzenia procesu, obranej linii obrony, jego dotychczasowej aktywności w zakresie inicjatywy dowodowej.

Z kolei uznanie przez sąd orzekający bezcelowości składanego wniosku dowodowego i związanego z tym zamiaru przedłużenia postępowania karnego może nastąpić tylko i wyłącznie, gdy sąd przekonany jest, iż wnioskodawca subiektywnie przeświadczony jest o niemożności korzystnej zmiany swojej sytuacji procesowej wskutek wnioskowanego dowodu. Dodatkowo sąd musi stwierdzić, że jest to również obiektywnie weryfikowalne w oparciu o całokształt ujawnionego już materiału dowodowego oraz zachowania wnioskodawcy. Nie mogą istnieć żadne wątpliwości co do tego, że złożony wniosek dowodowy nic merytorycznie nie zmieni i nie narusza nakazu dokonywania prawdziwych ustaleń faktycznych. Dokonanie przez sąd ustaleń we wskazanym powyżej zakresie pozwala w pewnym sensie sądowi na trudną ocenę uprzednią (aprioryczną) dowodu.

Natomiast ocena okoliczności, jaką jest przedłużenie procesu karnego, dotyczy istotnego jego przedłużenia. Czas trwania niemieckiego postępowania karnego jest oznaczony podobnie jak w procesie polskim, tj. „rozsądny/stosowny termin” (innerhalb einer angemessener Frist). W związku z tym przyjąć należy, że określenie czasu zawsze odnosi się do całokształtu przebiegu postępowania oraz zachowania wnioskodawcy. Tytułem przykładu wskazać należy, iż bezzasadność wnioskowanych tez dowodowych oraz znaczna ilość wskazywanych źródeł i środków dowodowych oznacza niemożność rozstrzygnięcia sprawy w rozsądnym terminie, tj. stosownym do wagi i zawiłości danej sprawy a tym samym uzasadnia przyjęcie zamiaru przedłużenia postępowania.

\section{Wnioski}

Podsumowując, prekluzja dowodowa w polskim procesie karnym rozumiana jako ograniczenie w czasie dopuszczalności przedstawiania sądowi przez strony dowodów na poparcie ich tez, niewątpliwie narusza naczelną zasadę procesową, jaką jest zasada prawdy materialnej. Wydaje się też, że stoi w sprzeczności do koncepcji 
prawa karnego procesowego jako gałęzi prawa publicznego. Niewątpliwie natomiast celem tej instytucji jest przede wszystkim przyspieszenie i usprawnienie postępowania. $\mathrm{W}$ analizowanym $\mathrm{w}$ niniejszych rozważaniach przepisie prawnym art. $170 \S 1$ pkt $5 \mathrm{kpk}$. chodzi o zapobieganie przeciaganiu sprawy wskutek instrumentalnego wykorzystywania przez strony prawa inicjatywy dowodowej. Można też wskazać, iż z drugiej strony przepis ten ma również mobilizować wnioskodawców do niezwłocznego przedstawienia dowodów, jakimi dysponują.

W związku z tym stwierdzić należy, iż interpretacja i stosowanie przepisu art. $170 \S 1$ pkt 5 kpk. (quasi-prekluzji dowodowej) nie może wypaczać istoty polskiego procesu karnego i prowadzić do wyroków merytorycznie niesłusznych i rażąco niesprawiedliwych. Natomiast rozumienie tej regulacji prawnej jako dyscyplinującego czasowego ograniczenia dla stron postępowania w przedmiocie przedstawiania sądowi wniosków dowodowych jest zgodne z celem rzetelnego procesu karnego, jakim jest rozstrzygnięcie sprawy w rozsądnym terminie. 


\title{
THE LIMITATION OF EVIDENCE IN THE POLISH CRIMINAL PROCEEDINGS BASED ON EXAMPLE OF THE ART. 170 § 1 PKT. 5 KPK.
}

\author{
SUMMARY
}

The matter of these considerations is the issue of limitation of evidence in the Polish criminal proceedings, understood as restriction of the evidence due to the passage of time.

As an example analysed in this study, the author has chosen the provision of article $170 \S 1$ point 5 . kpk. which, since 2003, provides a new basis for rejecting the application of evidence, when such proposal „obviously aimes to extend the criminal proceeding". The author's interpretation is based on the jurisdiction of the Supreme Court.

In this article the author also presents parallel legal solution and its interpretation in the German lawsuit. 